\title{
Wilkie's syndrome: a rare cause of intestinal obstruction
}

\author{
Sanoop Koshy Zachariah
}

Department of General, Gastrointestinal \& Laparoscopic Surgery, MOSC Medical College, Cochin, Kerala, India

\section{Correspondence to}

Professor Sanoop Koshy Zachariah, skzach@yahoo.com

Accepted 5 December 2013
CrossMark

\footnotetext{
To cite: Zachariah SK. BMJ Case Rep Published online: [please include Day Month Year] doi:10.1136/bcr-2013203059
}

\section{DESCRIPTION}

A 31-year-old woman was referred to our hospital, with recurrent episodes of profuse vomiting and upper abdominal pain associated with loss of appetite and dyspepsia since 2 months. She had no other comorbidities. She had been treated at another hospital with proton pump inhibitors,

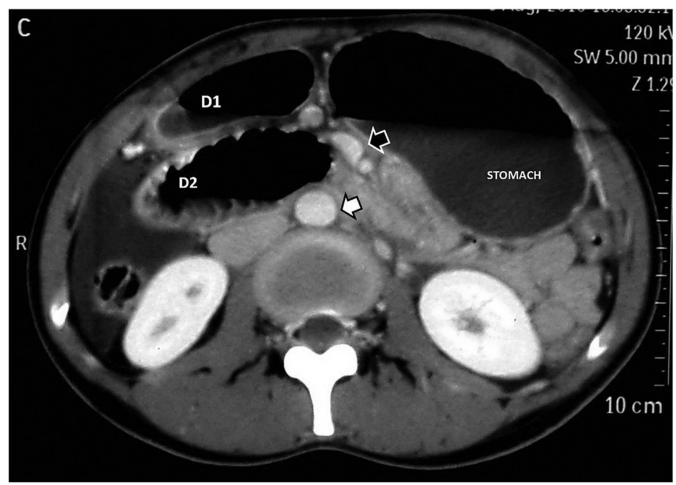

Figure 1 CT scan showing dilated stomach along with the first and second parts of the duodenum (D1 and D2). Calcifications can be seen within superior mesenteric artery (black arrow) and the aorta (white arrow). analgesics and intravenous fluids. She had a history of chronic anorexia and progressive loss of weight along with recurrent episodes of vomiting and upper abdominal pain. Clinical examination revealed dehydration, asthenicity (body mass index $18.8 \mathrm{~kg} / \mathrm{m}^{2}$ ), abdominal distension, epigastric tenderness and positive suction splash on auscultation. Laboratory investigations showed a total white cell count of $13500 \mathrm{~mm}^{3}$ and hypokalaemia (serum potassium: $3 \mathrm{mEq} / \mathrm{L}$ ). Plain radiograph of the abdomen revealed gastric dilation. Ultrasonography was unremarkable. Upper gastrointestinal endoscopy showed dilated stomach and proximal capacious duodenum. Contrast-enhanced CT (CECT) scan revealed grossly distended stomach and duodenum proximal to the third part of the duodenum at the level of the origin of superior mesenteric artery with abrupt narrowing at this level, suggestive of superior mesenteric artery syndrome/Wilkie's syndrome (figure 1). As conservative treatment failed, the patient underwent laparotomy after 10 days. At laparotomy, the stomach and the first and second parts of the duodenum were found to be greatly dilated and the offending superior mesenteric artery was seen clearly compressing the third part
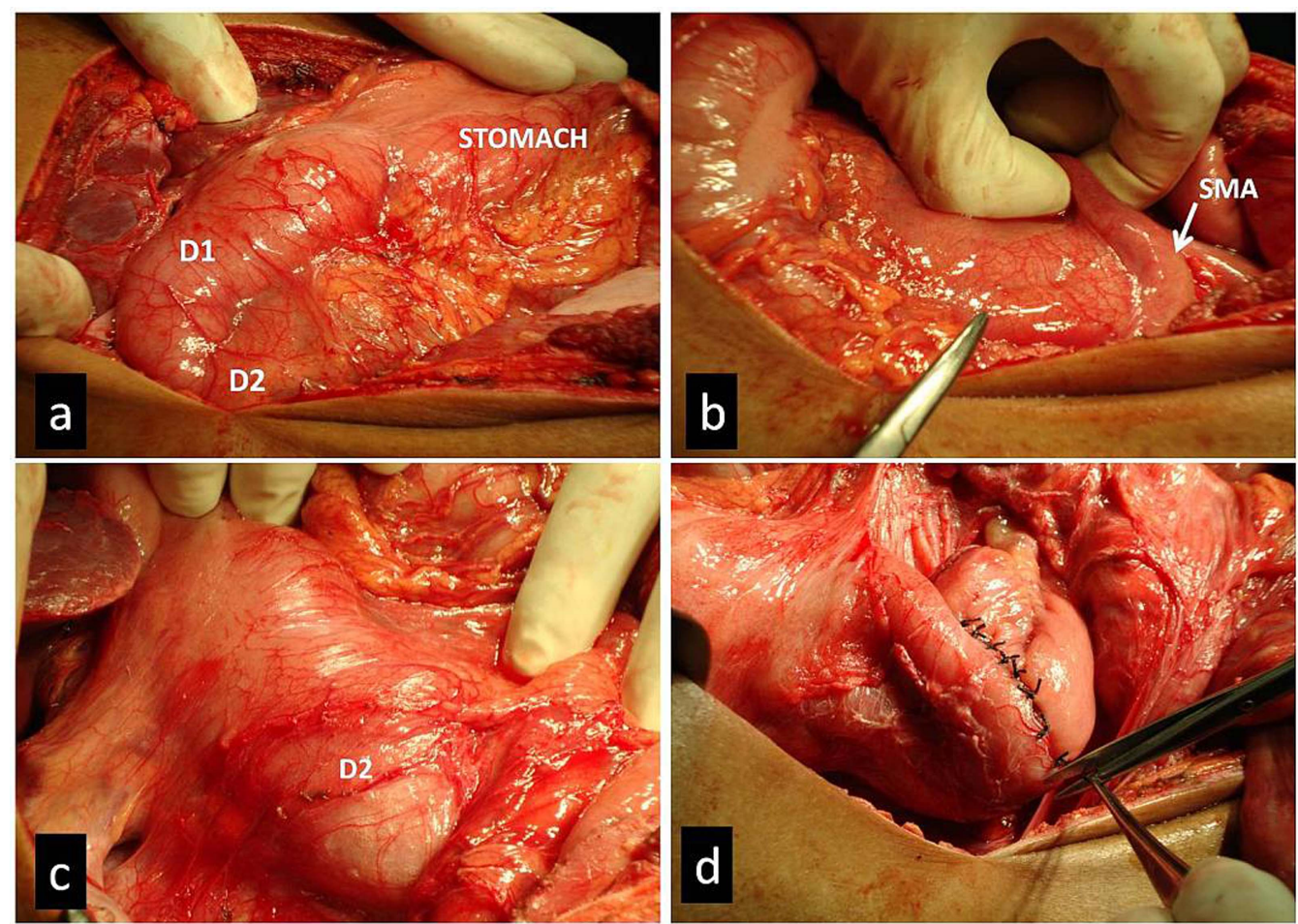

Figure 2 Operative photographs (A) showing dilated stomach along with the first and second parts of the duodenum (D1 and D2); (B) the superior mesenteric artery (SMA) can be well seen compressing the duodenum; (C) kocherisation of distended duodenum; (D) completed Roux-en-Y duodenojejunostomy (anastomosis is created between the duodenum and jejunum anterior to the SMA). 


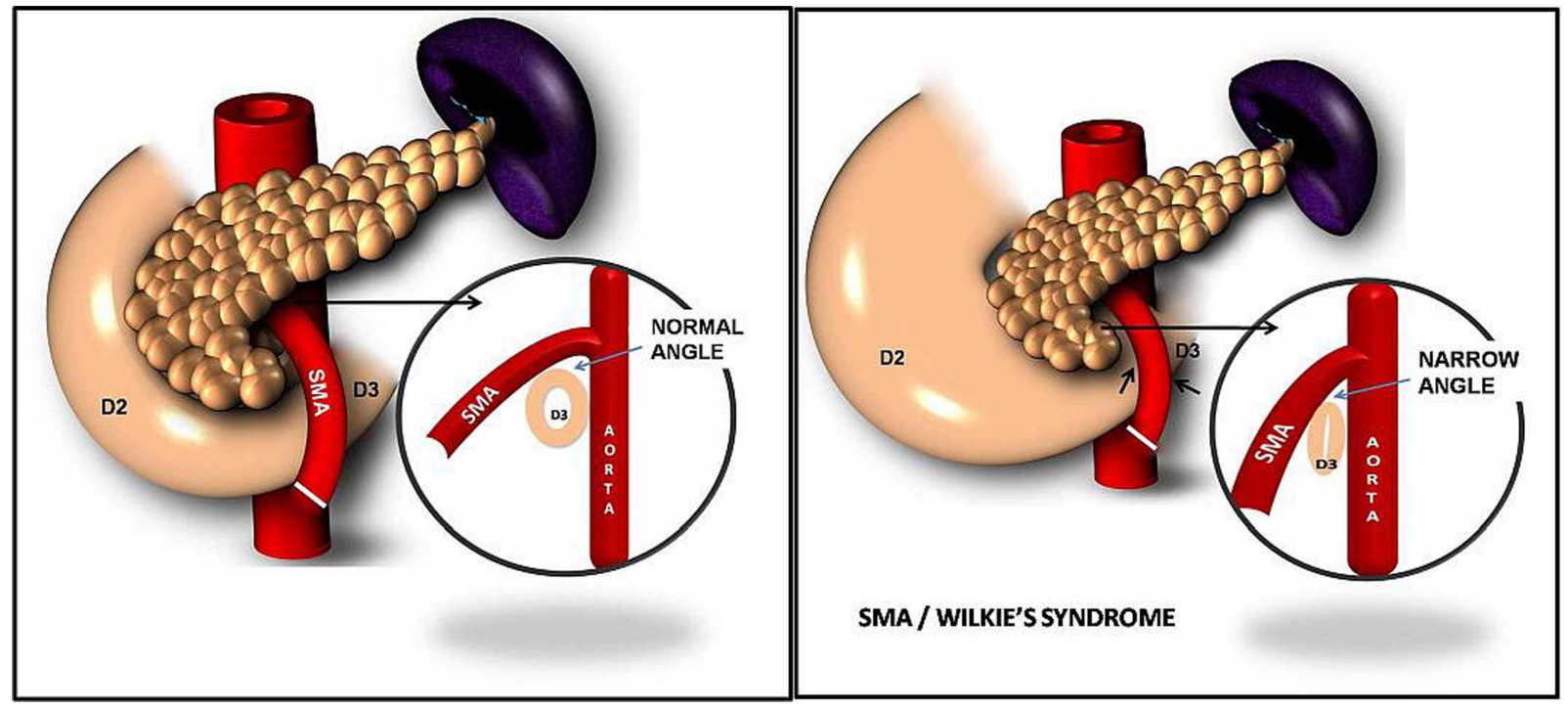

Figure 3 Illustration showing mechanism of compression of the third part of the duodenum (D3) due to narrowing of the angle between superior mesenteric artery (SMA) and aorta, leading to proximal duodenal distension.

\section{Learning points}

- Wilkie's syndrome is a rare cause of duodenal obstruction (incidence: $0.1-0.3 \%$ ), which is characterised by compression of the third portion of the duodenum between the superior mesenteric artery and aorta due to narrowing of aortomesenteric angle from $45^{\circ}$ (range between $38-56^{\circ}$ ) to about $6-25^{\circ}$ (figure 3). ${ }^{1}$

- Clinical diagnosis requires a high index of suspicion especially in a patient who presents with postprandial abdominal pain, vomiting and a recent history of significant weight loss.

- Contrast-enhanced CT scan is often diagnostic with typical findings of duodenal distension along with narrowing of the aortomesenteric angle and assessment of retroperitoneal fat. $^{2}$

- Surgical procedures (laparoscopic/laparotomy) include gastrojejunostomy, loop duodenojejunostomy, Roux-en-Y duodenojejunostomy and Strong's operation (ligament of Treitz division). ${ }^{3}$ of the duodenum (figure 2). A Roux-en-Y duodenojejunostomy was performed. The postoperative period was uneventful, and the patient was discharged on the 10th postoperative day. The patient is on a regular follow-up and is asymptomatic since 3 years.

\section{Competing interests None.}

Patient consent Obtained.

Provenance and peer review Not commissioned; externally peer reviewed.

\section{REFERENCES}

1 Wilkie DPD. Chronic duodenal ileus. Am J Med Sci 1927:643-9.

2 Unal B, Aktaş A, Kemal G, et al. Superior mesenteric artery syndrome: CT and ultrasonography findings. Diagn Interv Radiol 2005:90-5.

3 Matheos E, Vasileios K, loannis B, et al. Superior mesenteric artery syndrome. Case Rep Gastroenterol 2009:156-61.

Copyright 2014 BMJ Publishing Group. All rights reserved. For permission to reuse any of this content visit http://group.bmj.com/group/rights-licensing/permissions.

BMJ Case Report Fellows may re-use this article for personal use and teaching without any further permission.

Become a Fellow of BMJ Case Reports today and you can:

- Submit as many cases as you like

- Enjoy fast sympathetic peer review and rapid publication of accepted articles

- Access all the published articles

- Re-use any of the published material for personal use and teaching without further permission

For information on Institutional Fellowships contact consortiasales@bmjgroup.com

Visit casereports.bmj.com for more articles like this and to become a Fellow 